\title{
Seasonal hydrology influences energy channels in food webs of rivers in the lower Okavango Delta
}

Thethela Bokhutlo ( $\nabla$ thethela.bokhutlo@gmail.com )

Botswana International University of Science and Technology

Friedrich W. Keppeler

University of Wisconsin - Madison

Kirk O. Winemiller

Texas A\&M University

\section{Research Article}

Keywords: Basal production source, habitat size, spatial connectivity, trophic position, food web dynamics

Posted Date: February 8th, 2021

DOl: https://doi.org/10.21203/rs.3.rs-177949/v1

License: (9) This work is licensed under a Creative Commons Attribution 4.0 International License. Read Full License 


\section{Abstract}

Describing species interactions and resource use can elucidate patterns of energy flow in ecosystems. Here, we analyzed stable isotope ratios $\left(\delta^{13} \mathrm{C}\right.$ and $\left.\delta^{15} \mathrm{~N}\right)$ to infer seasonal variation in energy pathways and species foraging strategies in two rivers of the lower Okavango Delta, Botswana. We sampled fish during wet and dry seasons and estimated proportions of basal production sources assimilated by fish using Bayesian isotopic mixing models. We estimated modal trophic position for each fish population and assessed its correlation with the degree that biomass was supported by one production source. In the Boteti River during the wet season, biomass of most fishes was supported by food chains originating mainly from seston. During the dry season, C4 grasses assumed greater importance, and the degree of dependence on a single source was inversely related to trophic position. In the Boro River, seston was inferred to be an important production source supporting most species during both periods, and the degree of dependence on a single source was positively related to trophic position during the dry season, suggesting that species higher in the food web assimilated material disproportionately from one source during this period. Our findings support the idea that fish foraging habits shift in response to seasonal patterns of connectivity and habitat availability. We showed that consumers in river food webs are supported by multiple basal production sources and that seasonal hydrological pulsing, despite causing short-term changes in food web dynamics, may promote long-term population and community stability.

\section{Introduction}

Food webs in river-floodplain systems are complex with multiple spatial compartments linked via movements of water and organisms (Winemiller 2004; Layman et al. 2012). Network structure and stability are affected by the ability of consumers to switch their feeding according to spatial and temporal variation in food availability (Liem 1980; Winemiller 1989; Winemiller and Jepsen 1998). Consumers in dynamic systems may cross habitat boundaries to exploit resource pulses or areas with high productivity (Polis and Strong 1996; Vander Zanden and Vadeboncoeur 2002; McCann et al. 2005). Adaptive foraging and the ability to exploit alternative food resources based on availability can increase the probability of species persistence in fluctuating environments (Kondoh 2003). Therefore, a better understanding of food web ecology requires the characterization of variation in pathways of energy and matter transfer through time and across space.

Aquatic food webs are supported by both algal-grazer and detrital-microbial energy pathways (Winemiller 1990,1996; Vadeboncoeur et al. 2003; Moline et al. 2004; Mclntosh et al. 2017). These pathways are sometimes referred to as green versus brown food webs (Wolkovich et al. 2014; Zou et al. 2016). Numerous studies of aquatic ecosystems have emphasized the importance of the green food web (Rooney and McCann 2012; Roach and Winemiller 2015; McIntosh et al. 2017), presumably because, for most metazoan consumers, plant tissue is more easily digested and provides higher nutritional value than the biomass of detritus and associated microbial decomposers (Thorp and Delong 1994; Lewis et al. 2001). Whereas macrophytes may be abundant within streams and riparian areas, they usually do not directly contribute much material to the biomass of aquatic organisms at positions higher in food webs 
(Bunn et al. 2003). This appears to be due to the inability of most aquatic macroinvertebrates and vertebrates to digest and absorb nutrients from macrophyte tissues (Renaud et al. 1999; Cotner and Biddanda 2002). Nonetheless, a few studies suggest that heterotrophy and the brown food web may predominate in ecosystems with a high abundance and diversity of consumers but low aquatic primary productivity (Legendre and Rassoulzadegan 1995; Cotner and Biddanda 2002).

Hydroperiod stage and the dynamics of basal resources are major determinants of spatial and temporal shifts in predominant energy pathways and interactions in river food webs (McCann et al. 1998; Kondoh 2003). Using stable isotope analysis, several studies inferred that carbon and nitrogen originating from macrophytes supported fish biomass in rivers during high flow pulses (Jardine et al. 2012; Zeug and Winemiller 2008; Roach and Winemiller 2015; Ou and Winemiller 2016). A few fish species in the Amazon River in Brazil and the Apure River in Venezuela were reported to assimilate material derived primarily from terrestrial C4 grasses, a basal source that tends to have higher $13 \mathrm{C} / 12 \mathrm{C}$ ratios than other sources (Forsberg et al. 1993; Jepson and Winemiller 2007). In many fluvial systems, both materials originating from outside the aquatic ecosystem and production from within the aquatic ecosystem appear to support biomass of fish and other metazoan consumers, especially during low-flow periods (Bunn et al. 2003; Thorp and Delong 1994; Zeug and Winemiller 2008; Roach and Winemiller 2015; Ou and Winemiller 2016; Venarsky et al. 2020).

Perhaps the most comprehensive model seeking to predict general patterns of material and energy flow in river food webs is the river wave concept (RWC) (Humphries et al. 2014). The RWC equates river flow to waves traversing the landscape in both longitudinal and lateral dimensions. It posits that at the trough of the river wave (low flow), energy from in-stream primary production and local terrestrial inputs should predominate. During the ascending and descending limbs of the wave, upstream allochthonous inputs and downstream export of basal sources and consumers are important. However, at the crest of the wave (high flow), energy from terrestrial inputs and primary production in the floodplain assume greater importance (Humphries et al. 2014).

Our understanding of energy sources that support food webs of river-floodplain ecosystems and wetlands has increased in recent years, with a noticeable rise in investigations of river food webs in Africa (Hill et al. 2015; Taylor et al. 2017; Peel et al. 2019; Masese et al. 2020). Even so, the influence of wet-dry seasonality and flow pulses on aquatic food web dynamics is poorly understood in most regions of the world (McMeans et al. 2015; McIntosh et al. 2017). In this study, we sampled reaches in the Boro and Boteti rivers in the lower Okavango Delta, a large wetland complex located within a semiarid region of southern Africa, during high and low flow periods within one hydrological cycle. We investigated changes in carbon sources supporting fish biomass across a gradient of water residence time. During the study period, the study reach in the Boro River was ephemeral and experienced habitat fragmentation and eventual desiccation during the dry season. In contrast, the study reach in the Boteti River retained water throughout the study without loss of longitudinal habitat connectivity. We inferred seasonal changes in predominant energy pathways and trophic structure using stable isotope ratios of carbon and nitrogen. Carbon and nitrogen stable isotopes are useful tracers in food web research because carbon ratios often 
can be used to estimating the energy sources supporting consumer biomass, and nitrogen ratios estimate organisms' vertical trophic positions (Minagawa and Wada 1984; Vander Zanden and Rasmussen 1999).

We hypothesized that food webs in both rivers would follow predictions of the RWC. First, we expected energy from autochthonous production within the river channel and local allochthonous inputs to support fish biomass during periods with low flows. During high flows, production sources from the floodplain should provide the most important inputs to aquatic food webs, as predicted by the RWC. Second, we predicted that in both rivers, many fish species would be trophic generalists, linked to many food chains and diverse basal production sources. However, a few species were predicted to be trophic specialists linked to fewer food chains originating from only a few sources. Third, we postulated that species integrating multiple basal sources and food chains would be positioned higher in the food web, and those deriving large proportions of their tissues from one source would be positioned lower in the food web. This is because fish positioned higher in the food web have more potential to integrate inputs from multiple food chains that originate from different basal sources (Rooney et al. 2008; McCann 2011).

\section{Methods}

Study area

The Okavango Delta is the largest water body in Botswana, and it is supported by the annual flood pulse that originates in the Angolan highlands. About $16 \mathrm{~km}^{3}$ of water enters the Delta every year around December/January at Mohembo, the majority of which (96\%) is lost to evapotranspiration, $2 \%$ is lost through seepage, and only $2 \%$ leaves the wetland as surface flow around May/June, mainly through the Boro River channel (Ellery and McCarthy 1998). The Boro River forms a confluence with the Thamalakane River at Matlapaneng and flows in the south-west direction until it branches at Dikgathong to form Boteti River and Nhabe River. Generally, the lower Delta experiences increased flows and flooding between May and October, and dry conditions with reduced flows from November to April (Akoko et al. 2013).

We analyzed food webs by sampling basal resources and fish in the Boro and Boteti rivers during wet and dry seasons within one annual flood cycle. We sampled four sites in the Boro River along a c. $20 \mathrm{~km}$ reach from the buffalo fence to the Boro-Thamalakane junction at Matlapaneng (Fig 1). The substrate in this reach is fine sand within the main river channel, along channel margins, and in floodplains. Submerged aquatic macrophytes (waterlily), and hippo grass were common in this reach. Deciduous trees, including Acacia species, were common in riparian areas. Two sites were sampled in the Boteti River in a c. 30-km reach from the Thamalakane-Boteti River junction to Chanoga Lagoon. The substrate in Boteti River is mainly solid bedrock, boulders, and clay within the main river channel. Channel margins and floodplains consist of silt and sand with pebbles in some parts. Aquatic macrophytes and riparian vegetation were similar those in the Boro River. Hippopotamus (Hippopotamus amphibious) were frequently sighted throughout the study period in the Boteti River reach. At this location, channel width 
varied little with flow level; the only exception was Chanoga Lagoon where the channel widened $\sim$ twofold between low flow and bankful conditions.

Fish sampling

Fishes were sampled using a nylon multifilament gillnet that had 11 panels of different mesh sizes (12-, 16-, 22-, 28-, 35-, 45-, 57-, 73-, 93-, 108- and 150-mm stretched mesh), each with a length of 10-m and 2.5$\mathrm{m}$ depth. Fish also were collected using a seine net (length $=7.6-\mathrm{m}$, depth $=1.8-\mathrm{m}$, mesh $=3.2-\mathrm{mm}$ ) and two double-ended fyke nets with 1.2-m D-openings and 25-mm mesh. The gillnet was set in the main channel, and fyke nets were set perpendicular to the main channel stretching from the riverbank into the floodplain. The gillnet and fyke nets were set overnight from $c .1800 \mathrm{~h}$ in the evening and retrieved the following morning at $c .0600 \mathrm{~h}$. Seining was conducted opportunistically during the daytime when conditions were deemed safe from crocodiles. Fish specimens were quickly euthanized (TAMU AUP IACUC 2017-0069), and samples of muscle tissue were obtained from the right flank below the base of the dorsal fin of select specimens. Voucher specimens were fixed in formalin and preserved in ethanol for archiving at the Biodiversity Research and Teaching Collection at Texas A\&M University, College Station. Specimens were identified to species level based on keys and illustrations in Skelton (2001).

Collection and preparation of isotopic samples

In each river and during each season, tissue samples were obtained from six basal resources (seston, riparian C3 plants, terrestrial C4 grasses, periphyton, and waterlily) and fishes. Periphyton was obtained by gently scraping submerged tree branches to collect biofilm. Seston (which may consist of mostly allochthonous or autochthonous materials depending on the hydroperiod stage) was obtained from surface water and filtered through pre-combusted Whatman GF/F filters with a pore size of $0.7 \mu \mathrm{m}$ (methods follow those reported in Ou and Winemiller 2016). We collected leaves of riparian trees, shrubs, and grasses (allochthonous sources) that were prevalent along channel margins and in the floodplain. We also collected leaves and stems of dominant floating (hippo grass [Vossia cuspidate]; Cyperus articulates) and submerged aquatic macrophytes (Nesaea crassicaulis; Rotala myriophylloides; Ceratophyllum demersum) from the main river channel. We considered waterlily to be a separate source from other aquatic macrophytes because of its distinct isotope signature. We also collected muscle tissue from snails (Radix spp.) to serve as the isotopic baseline (aquatic primary consumer) for estimation of fish trophic positions (see below). To account for individual variability in the isotope values of fish and basal resources, the goal was to obtain 3-5 samples of each fish species and basal resource category at each site during each survey period. 
Basal sources and fish tissues were sampled during the flood period (August 10-14, 2017 and October 12-20, 2017) and low-flow period (December 2-8, 2017 and February 16-25, 2018). Thus, flood period samples were obtained 3-5 months after the beginning of the wet season, and low-flow samples were obtained 1-3 months after the start of the dry season. The carbon isotopic half-life of fish muscle tissue ranges from 10-60 days with a mean of 25 days (Boecklen et al. 2011). Therefore, we assumed that isotope ratios of consumers reflected feeding history during the season when the samples were collected (Hobson and Clark 1992; Bearhop et al. 2004; Ou and Winemiller 2016). Basal source and fish muscle tissue samples were packaged in plastic bags and preserved in salt for later analysis in the laboratory.

Following the protocol described by Arrington and Winemiller (2002), the salt-preserved material was soaked in distilled water and then rinsed to remove the salt. Rinsed material was dried in an oven at $60^{\circ} \mathrm{C}$ for $48 \mathrm{~h}$ and then ground into a fine powder using mortar and pestle. Powdered subsamples were weighed to the nearest $0.02 \mathrm{mg}$ and packaged into Ultrapure ${ }^{\circledR}$ tin capsules. Analyses of carbon and nitrogen isotope ratios were carried out at the Analytical Chemistry Laboratory, Institute of Ecology, University of Georgia, USA. Stable isotopes of carbon and nitrogen were analyzed following standard procedures. Isotope ratios were reported in parts per thousand (\%o) relative to the Pee Dee Belemnite (C) and atmospheric nitrogen $(\mathrm{N})$ such that; $\delta \mathrm{X}(\% \mathrm{o})=\left[\left(\mathrm{R}_{\text {sample }} / \mathrm{R}_{\text {standard }}\right)-1\right] \times 10^{3}$, where $\mathrm{X}={ }^{13} \mathrm{C}$ or ${ }^{15} \mathrm{~N}$, and $\mathrm{R}$ $={ }^{13} \mathrm{C} /{ }^{12} \mathrm{C}$ or ${ }^{15} \mathrm{~N} /{ }^{14} \mathrm{~N}$.

Data analysis

We used Bayesian stable isotope mixing models to infer the proportion of basal sources assimilated by fish. We adjusted for trophic fractionation (TF) of $\delta^{15} \mathrm{~N}$ in the models using values (TF of $\delta^{15} \mathrm{~N}=3.37 \pm$ 1.30 [mean \pm SD]) for Southern African fishes obtained from Taylor et al. (2017), and $\delta^{13} \mathrm{C}$ TF was obtained by averaging values ( $T F$ of $\delta^{13} \mathrm{C}=0.54 \pm 0.53$ ) from the literature (Bastos et al. 2017). We evaluated isospace plots to ensure that consumer isotopic values fell within the space defined by $\delta^{13} \mathrm{C}$ and $\delta^{15} \mathrm{~N}$ values of potential resource sources (Phillips et al. 2014; Arantes et al. 2019). Lipid correction was not considered to be necessary because the $\mathrm{C}: \mathrm{N}$ ratio of fish muscles was small (Post et al. 2007). Following the approach reported by Ou and Winemiller (2016), we ran isotopic source mixing models for individual fish species in each river and season within a Bayesian framework using the $\mathrm{R}$ package simmr (Parnell 2020, R Core Team 2020). Chains of all mixing models converged (Gelman-Rubin Statistic <1.1), and we recorded the median contribution of each source to fish biomass with $95 \%$ credible intervals. We determined the ability of the models to adequately separate food sources assimilated by fish through the assessment of correlations between sources within the isospace. Except for a few relatively high correlations between sources, which is a common problem for stable isotope mixing models (Phillips et al. 2014), isotopic discrimination among sources was sufficient to allow models to estimate proportional assimilation among alternative sources. 
We estimated trophic position using the R package tRophicPosition which is based on the Bayesian model proposed by Quezada-Romegialli et al. (2018). We used the mean $\delta^{15} \mathrm{~N}$ value of snails (aquatic consumer at trophic level 2) as our baseline (Arantes et al. 2019), and both $\delta^{15} \mathrm{~N}$ and $\delta^{13} \mathrm{C}$ TF values described above to estimate fish trophic position (McCutchan et al. 2003). We used linear regression to estimate the relationship between the degree of dependence on a single major basal source and the modal trophic position for fish species in both rivers during each season. The response variable was the modal trophic position obtained from the probability distribution of estimated trophic positions for each species during a particular period/season, and the explanatory variable was the highest value for estimated mean percent contribution among basal sources for that species during the same period.

\section{Results}

Stable isotope signatures of basal production sources and fishes

A total of 220 samples from six basal sources was collected during the study period (Table 1). A greater number of samples was obtained during the dry season (Boteti $=70$; Boro $=66$ ) compared to the wet season (Boteti $=25$; Boro $=59$ ). Terrestrial $\mathrm{C} 4$ grass had the highest $\delta^{13} \mathrm{C}$ values among plants (Fig 2 and 3 ) with average values of -12.47 ( $s d=0.72)$. Seston, $\mathrm{C} 3$ plants, periphyton, and aquatic macrophytes (including waterlily) had similar $\delta^{13} \mathrm{C}$ values ranging from -35 to -25 . We found high variation and overlap in $\delta^{15} \mathrm{~N}$ values between the different basal resources (Table 1)

Tissue samples were collected from 486 fish specimens representing 25 species (Table 2). In both rivers, more species were collected during the dry season (Boteti $=19$ species; Boro $=21$ species) compared to the wet season (Boteti $=15$ species; Boro $=17$ species). Herbivorous and detritivorous fishes tended to have lower values for $\delta^{15} \mathrm{~N}$ than carnivorous fishes. $\delta^{13} \mathrm{C}$ values were low for most species ( -30 to -20$)$ with relatively high variation associated with seasonal and spatial patterns (Table S1, Fig 2 and 3 ).

Source contributions to consumers

Across rivers and seasons, the biomass of nearly all fish species likely was supported by multiple basal sources (Table S1). Nonetheless, various source contributions to fish biomass varied substantially depending on location and season for several species.

During the wet season, three basal resources (seston, riparian C3 plants, and terrestrial C4 grass) were each estimated to contribute more than 20 percent to the biomass of several fish species in the Boro River (Fig 4). This inference is based on the mean value from the probability distribution of mixing model 
estimates of source contributions for each species. Five out of seventeen $(29 \%)$ species likely derived more than 30 percent of their muscle tissue mainly from one source. Seston was estimated to be a major production source supporting the biomass of four out of these five species $(80 \%)$ that derived more than 30 percent of their muscle tissue from a single source, i.e., predators $\mathrm{H}$. cuvieri and $\mathrm{S}$. intermedius, the invertivorous mormyrid M. altisambesi, and the herbivorous cichlid T. sparmanii. Terrestrial C4 grass was at the base of food chains supporting the biomass of the invertivorous straight-fin barb E. paludinosus.

During the dry season, aquatic macrophytes replaced riparian C3 plants among the three basal resources that were estimated to contribute more than 20 percent to the biomass of one or more fish species in the Boro River (Fig 5). Nine out of twenty-one (43\%) species were estimated to derive more than 30 percent of their muscle tissue mainly from one source. Seston was an important basal source in food chains supporting the biomass of seven out of these nine species (78\%), including predators ( $C$. gariepinus, $H$. cuvieri, and S. intermedius), invertivores (E. paludinosus, M. altisambesi, and Synodontis spp.) and the herbivorous cichlid T. sparmanii. Waterlily was at the base of food chains supporting the biomass of two species (22\%) of invertivorous cichlids $P$. acuticeps and $S$. carlottae.

The same three basal resources (seston, aquatic macrophytes, and terrestrial C4 grass) were each estimated to contribute more than 20 percent to the biomass of several fishes in the Boteti River during the wet season (Fig 6). Eleven out of fifteen (73\%) species derived more than 30 percent of their muscle tissue mainly from one source. Seston was estimated to be a major production source supporting the biomass of seven out of these eleven species (64\%), including predators (S. intermedius and $S$. altus) and invertivores (P. okavangoensis, P. acuticeps, M. altisambesi, Synodontis spp., and B. lateralis). Aquatic macrophytes were the most important basal source in food chains supporting the biomass of two predatory species, $H$. vittatus and $C$. ngamensis. The predatory African pike $H$. cuvieri and herbivorous cichlid $C$. rendalli were primarily supported by terrestrial $\mathrm{C} 4$ grass.

During the dry season, four basal sources (seston, periphyton, riparian C3 plants, and terrestrial C4 grass) were each estimated to contribute more than 20 percent to the biomass of one or more fishes in the Boteti River (Fig 7). Four out of nineteen (21\%) species derived more than 30 percent of their muscle tissue mainly from a single source. Among these, terrestrial C4 grass was at the base of food chains leading to the biomass of two species, the invertivorous straight-fin barb and predatory African pike. Periphyton was estimated to be the major basal source contributing to the biomass of the detritivorous cichlid $O$. andersonii, and seston was estimated to be the basal source in food chains supporting biomass of the invertivorous mormyrid $P$. okavangoensis.

Food web length and trophic position of consumers 
Modal trophic position values derived from our Bayesian models indicated that the food web length was lower than 4.5 in both rivers. Serranochromis altus was the top predator in both rivers during the wet season. During the dry season, Clarias gariepinus was the top predator in the Boro river while Serranochromis macrocephalus was the top predator at the Boteti River. Although some species were classified as herbivores and detritivores in previous studies, our modal trophic position estimates indicate they occupy trophic positions greater than $2(\mathrm{~min}=2.42)$ in all sites and seasons (Table $S 2-S 5)$.

Relationship between the degree of dependence on major basal sources and modal fish trophic position

In the Boro River, the relationship between trophic position and the degree of dependence on a single major basal source was negative during the wet season $\left(y=4.2-1.3 x, R^{2}=0.52, F=11.87, D F=11, t=\right.$ $-3.45, P=0.005$, Fig 8), and positive during the dry season $\left(y=2.3+2.1 x, R^{2}=0.43, F=7.63, D F=10, t=\right.$ $2.76, P=0.02)$. In the Boteti River, trophic position did not vary with the degree of dependence on a single major basal source during the wet season $\left(y=3.5+0.04 x, R^{2}=0.001, F=0.006, D F=13, t=0.08, P=\right.$ $0.94)$, and the relationship was negative and significant during the dry season $\left(y=4.4-3.1 x, R^{2}=0.51, F\right.$ $=12.4, \mathrm{DF}=12, \mathrm{t}=-3.52, \mathrm{P}=0.004)$.

\section{Discussion}

Fishes in the Lower Okavango Delta have diverse trophic niches, and most species appeared to be supported by multiple basal production sources. Seston was estimated to be the most important basal source supporting most fishes in the Boro River during both wet and dry seasons. During the wet season in the Boteti River, seston was at the base of food chains supporting the much of the biomass of most fish species. The composition of seston samples was not determined, but visual inspection of the samples indicated fine particulate organic matter (detritus) that probably originated from some combination of algae, cyanobacteria, and macrophyte tissues (Peel et al. 2019). Although not a dominant input, C4 grasses assumed greater importance in the Boteti food web during the dry season, suggesting that at least some fish and/or macroinvertebrates that are consumed by carnivorous fishes changed their foraging strategies seasonally in response to shifts in resource availability. Although the dynamics of seston production are undocumented in this system, our results are consistent with the idea that both autochthonous and allochthonous resources should be major inputs to aquatic food webs in riverfloodplain ecosystems (Humphries et al. 2014). Seston production may vary seasonally, with higher proportions of seston deriving from autochthonous sources during the dry season, whereas the contribution of allochthonous sources may be greater during the wet season (Ellis et al. 2012). Interestingly, C4 grasses were a more important input to the aquatic food web during the dry season when flows were minimal and access to the floodplain was restricted. One explanation for this could be a time 
lag between the senescence and death of grasses while submersed during the flood, and the conditioning of grass tissue by microbial decomposers that increases its nutritional value for metazoan consumers.

Although most fishes could have consumed variable fractions of all five of the basal production sources obtained for isotopic analysis, the biomass of several species was estimated to have been largely supported by just one or two sources. In the Boro River, several species positioned higher in the food web may have assimilated a large fraction of organic matter derived from a single major basal source during the dry season. Assimilation of larger fractions of material from a single source during low-flow conditions of the dry season is consistent with the idea that habitat reduction and isolation results in stronger trophic interactions (McCann et al. 2005). During the study period, the Boro River study reach underwent habitat fragmentation when flows declined. At the peak of the dry season, the channel contained a series of isolated pools that gradually shrank, with some of them eventually drying. Isolation within shrinking aquatic habitats resulted in greater reliance of fishes on local sources of production, a pattern observed in other tropical rivers (Taylor et al. 2006; Jardine et al. 2012). Generalist predators may exhibit specialized foraging habits in isolated pools during the dry season when resources are scarce and switch to a diverse diet during the wet season when more resources become available (Balcombe et al. 2015). During the wet-season flood pulse, both longitudinal and lateral connectivity increased the amount of aquatic habitat and the potential for fish to disperse. Consequently, fish movement would have linked local food webs that had been spatially subdivided, with generalist predators expanding their niche breadth, especially in adjacent floodplains where primary and secondary production is high (Winemiller and Jepsen 1998, Høberg et al. 2002; Lindholm et al. 2007). These patterns support Liem's paradox, which posits that fish with obvious adaptations for trophic specialization should nonetheless retain the ability to feed on diverse food items to enable exploitation of profitable resources when they become abundant (Liem 1980).

In the Boteti River, fish species positioned higher in the food web appeared to assimilate organic matter from multiple sources during the dry season, a pattern similar to that observed in Boro River during the wet season. This pattern could result from contrasting seasonal patterns of habitat size and connectivity in the two rivers. Variation in flow conditions and habitat connectivity in fluvial systems are significant determinants of aquatic primary production and resource availability for aquatic consumers (Junk et al. 1989; Jardine et al. 2012, Humphries et al. 2014; Garcia et al. 2017; Venarsky et al. 2020). For example, habitats with different degrees of water residence time may have different rates for ecosystem productivity and heterotrophy. Carbon fixation tends to be lower in ephemeral than perennial streams in North America (Febria et al. (2015), and turnover from microbial respiration was found to be lower in ephemeral streams in Germany (Gerull et al. 2011).

The Boteti River study reach remained longitudinally connected throughout the study period. However, connectivity in the lateral dimension was reduced when flows declined during the dry season. Predatorprey interactions intensify during the dry season when fishes move from the floodplain into more restricted habitat within the river channel (Winemiller 1990; Bogan and Lytle 2007; McHugh et al. 2010). Higher predator densities in the river channel could result in competition that causes fish to disperse 
along the river corridor and thereby encounter a greater diversity of food resources. This could explain why species higher in the food web assimilated material derived from multiple basal sources during the dry season in the Boteti River. In fluctuating environments, consumers should forage preferentially on the most abundant and nutritious resources (Kondoh 2003; Forest et al. 2008). This opportunity presents itself to fishes at all trophic levels during the wet season in Boteti River, when aquatic habitat volume and connectivity increase.

Our results suggest that in the Boro River, most fishes switched from feeding mostly from food chains originating from seston during the dry season to those supported by terrestrial $\mathrm{C} 4$ grass during the wet season. Whereas $\mathrm{C} 4$ grasses generally have low direct nutritional value when compared to other production sources (Minson 1971) and generally are reported to be minor contributors to fish biomass (Arantes et al. 2019), there is some evidence that C4 grasses may be the foundation of food chains that support the biomass of at least some fishes in tropical river-floodplain systems. As water levels fall in floodplains, biomass from decomposing C4 grasses is deposited in sediments; this material can enter aquatic food chains during the flood pulse when detritivores feed on this material and associated microorganisms that are decomposers (Høberg et al. 2002; Cole et al. 2011). For example, C4 grasses were inferred to be important basal sources in food chains supporting the biomass of air-breathing fishes that are common in floodplains of the Lower Mekong Basin (Ou and Winemiller 2016). Similarly, C4 grasses were important basal sources supporting food chains of air-breathing catfishes in the genus Clarias that were collected from the floodplains of the Oueme River in Benin (Jackson et al. 2013). In Boro River, the catfish Clarias gariepinus switched from being supported mostly by food chains originating from seston during the dry season to those supported by terrestrial C4 grass when the floodplain was inundated during the wet season.

Most fishes in the Boteti River were supported by food chains originating from seston during the wet season. During the dry season, their support shifted to energy and material pathways with terrestrial C4 grass as the production source. By comparison, organic material derived from the floodplain was found to support more than half of the fish biomass during the dry season in Cooper Creek, a dryland river in south-western Queensland, Australia (Burford et al. 2008). Okavango fishes were unable to forage in floodplains during the dry season; however, hippopotamuses were frequently sighted in the Boteti River throughout the study, and these megaherbivores could have transferred material from C4 grasses between terrestrial and aquatic habitats. Hippos were estimated to deposit $~ 36,000 \mathrm{~kg}$ of dung per day in the Mara River in Kenya (Subalusky et al. 2015), and this dung is reported to contain large proportions of terrestrial C4 grasses that support aquatic food webs (Masese et al. 2015). Therefore, terrestrial C4 grass could have entered aquatic food chains during the dry season in the Boteti River as undigested material in hippopotamus dung or through the microbial-loop energy pathway within the main river channel. Microbes colonize organic matter, and microbial metabolism has been shown to increase under low-flow conditions, leading to rapid mobilization of nutrients to primary producers that are subsequently consumed by aquatic invertebrates (Closs and Lake 1994; Finlay and Kendall 2007). Our results suggest that two invertivores (Brycinus lateralis and Marcusenius altisambesi) and an omnivore (Schilbe intermedius) were supported largely by seston during the wet season and C4 grass during the dry season, 
with grass and possibly even seston likely associated with microbial processing. The cichlid Oreochromis andersonii was captured in the Boteti River only during the dry season. Isotopic analyses estimated that periphyton was the most important basal source supporting biomass of this detritivore, which may have fed on algae and other material in biofilms either directly or indirectly in the form of detritus and associated microbes (Bunn et al. 2003; Winemiller and Kelso-Winemiller 2003; Reid et al. 2008; Peel et al. 2019).

Our findings indicate that seasonal changes in connectivity and aquatic habitat size likely drove changes in basal resource availability and the predominant energy pathways supporting fish biomass in the Lower Okavango Delta. Notable is the major role of seston and terrestrial C4 grass in supporting food chains that support fishes in Boteti River, which agrees with a prediction from the river wave concept that under low-flow conditions during the dry season, aquatic food webs are supported by both in-channel primary production and allochthonous material from riparian plants (Humphries et al. 2014). Adaptive foraging is one mechanism that could enhance food web resilience to fluctuations caused by extreme seasonal hydrology in the lower Okavango Delta. Our findings support previous claims that maintenance of a relatively natural flow regime is critical for maintenance of biodiversity and productivity of river-floodplain ecosystems (Junk et al. 1989; Winemiller and Jepson 1998; Poff et al. 1997; Winemiller 2004; Zeug and Winemiller 2008; Jardine et al. 2012; Roach 2013; Humphries et al. 2014; Arantes et al. 2019). The annual flood pulse expands the aquatic habitat of the lower Okavango Delta and provides fish and other aquatic organisms with access to abundant autochthonous and allochthonous resources, including basal sources with high nutritional value. In theory, the extensive multi-channel foraging that results from these temporal and spatial dynamics enhances the stability of these complex ecological systems (Kondoh 2003; Wolkovich et al. 2014).

\section{References}

Akoko E, Atekwana EA, Cruse AM, Molwalefhe L, Masamba WRL (2013) River-wetland interaction and carbon cycling in a semi-arid riverine system: the Okavango Delta, Botswana. Biogeochemistry 114: 359380. https://doi: 10.1007/s10533-012-9817-x.

Arantes CC, Winemiller KO, Petrere M, Freitas CEC (2019) Spatial variation in aquatic food webs in the Amazon River floodplain. Freshwater Science 38: 213-228. https://doi: 10.1086/701841.

Arrington DA, Winemiller, KO (2002) Preservation Effects on Stable Isotope Analysis of Fish Muscle. Transactions of the American Fisheries Society 131: 337-342. https://doi: 10.1577/15488659(2002)131<0337: peosia>2.0.co;2.

Balcombe SR, Turschwell MP, Arthington AH, Fellows CS (2015) Is fish biomass in dryland river waterholes fuelled by benthic primary production after major overland flooding? Journal of Arid Environments 116: 71-76. https://doi: 10.1016/j.jaridenv.2015.01.020. 
Bastos RF, Corrêa F, Winemiller KO, Garcia AM (2017) Are you what you eat? Effects of trophic discrimination factors on estimates of food assimilation and trophic position with a new estimation method. Ecological Indicators 75: 234-241. https://doi: 10.1016/j.ecolind.2016.12.007.

Bearhop S, Adams CE, Waldron S, Fuller RA, Macleod H (2004) Determining trophic niche width: a novel approach using stable isotope analysis. Journal of Animal Ecology 73: 1007-1012. https://doi:

10.1111/j.0021-8790.2004.00861. x.

Boecklen WJ, Yarnes CT, Cook BA, James AC (2011) On the Use of Stable Isotopes in Trophic Ecology. Annual Review of Ecology, Evolution, and Systematics 42: 411-440. https://doi: 10.1146/annurev-ecolsys102209-144726.

Bogan MT, Lytle DA (2007) Seasonal flow variation allows 'time-sharing' by disparate aquatic insect communities in montane desert streams. Freshwater Biology 52: 290-304. https://doi: 10.1111/j.13652427.2006.01691. $x$.

Bunn SE, Davies PM, Winning M (2003) Sources of organic carbon supporting the food web of an arid zone floodplain river. Freshwater Biology 48: 619-635. https://doi: 10.1046/j.1365-2427.2003.01031. x.

Burford MA, Cook AJ, Fellows CS, Balcombe SR, Bunn SE (2008) Sources of carbon fuelling production in an arid floodplain river. Marine and Freshwater Research 59: 224-234. https://doi: 10.1071/mf07159.

Closs GP, Lake PS (1994) Spatial and Temporal Variation in the Structure of an Intermittent-Stream Food Web. Ecological Monographs 64: 2-21. https://doi: 10.2307/2937053.

Cole JJ, Carpenter SR, Kitchell J, Pace ML, Solomon CT, Weidel B (2011) Strong evidence for terrestrial support of zooplankton in small lakes based on stable isotopes of carbon, nitrogen, and hydrogen. Proceedings of the National Academy of Sciences 108: 1975-1980. https://doi: 10.1073/pnas.1012807108.

Cotner JB, Biddanda BA (2002) Small Players, Large Role: Microbial Influence on Biogeochemical Processes in Pelagic Aquatic Ecosystems. Ecosystems 5: 105-121. https://doi: 10.1007/s10021-0010059-3.

Ellery W, McCarthy T (1998) Environmental change over two decades since dredging and excavation of the lower Boro River, Okavango Delta, Botswana. Journal of Biogeography 25: 361-378. https://doi: 10.1046/j.1365-2699.1998.252168. x.

Ellis EE, Keil RG, Ingalls AE, Richey JE, Alin SR (2012) Seasonal variability in the sources of particulate organic matter of the Mekong River as discerned by elemental and lignin analyses. Journal of Geophysical Research: Biogeosciences B 117: 1-15. https://doi: 10.1029/2011jg001816.

Febria CM, Hosen JD, Crump BC, Palmer MA, Williams DD (2015) Microbial responses to changes in flow status in temporary headwater streams: a cross-system comparison. Frontiers in Microbiology 6: 
https://doi: 10.3389/fmicb.2015.00522.

Finlay JC, Kendall C (2007) Stable isotope tracing of temporal and spatial variability in organic matter sources to freshwater ecosystems. In: Michener R, Lajtha K (ed) Stable isotopes in ecology and environmental science, 2nd edn. Blackwell Publishing, Malden, pp. 283-333.

Forest A, Sampei M, Makabe R, Sasaki H, Barber DG, Gratton Y, Wassmann, P, Fortier L (2008) The annual cycle of particulate organic carbon export in Franklin Bay (Canadian Arctic): Environmental control and food web implications. Journal of Geophysical Research 113: 1-14. https://doi: 10.1029/2007jc004262.

Forsberg BR, Araujo-Lima CARM, Martinelli LA, Victoria RL, Bonassi JA (1993) Autotrophic Carbon Sources for Fish of the Central Amazon. Ecology 74: 643-652. https://doi: 10.2307/1940793.

Garcia AM, Winemiller KO, Hoeinghaus DJ, Claudino MC, Bastos R, Correa F, Huckembeck S, Vieira J, Loebmann D, Abreu P, Ducatti C (2017) Hydrologic pulsing promotes spatial connectivity and food web subsidies in a subtropical coastal ecosystem. Marine Ecology Progress Series 567: 17-28. https://doi: 10.3354/meps12060.

Gerull L, Frossard A, Gessner MO, Mutz M (2011) Variability of heterotrophic metabolism in small stream corridors of an early successional watershed. Journal of Geophysical Research 116: https://doi: 10.1029/2010jg001516.

Hill JM, Jones RW, Hill MP, Weyl OLF (2015) Comparisons of isotopic niche widths of some invasive and indigenous fauna in a South African river. Freshwater Biology 60: 893-902. https://doi:

$10.1111 /$ fwb. 12542 .

Høberg P, Lindholm M, Ramberg L, Hessen DO (2002) Aquatic food web dynamics on a floodplain in the Okavango delta, Botswana. Hydrobiologia 470: 23-30.

Hobson KA, Clark RG (1992) Assessing Avian Diets Using Stable Isotopes I: Turnover of 13C in Tissues. The Condor 94: 181-188. https://doi: 10.2307/1368807.

Humphries P, Keckeis H, Finlayson B (2014) The River Wave Concept: Integrating River Ecosystem Models. BioScience 64: 870-882. https://doi: 10.1093/biosci/biu130.

Jackson AT, Adite A, Roach KA, Winemiller KO (2013) Primary production, food web structure, and fish yields in constructed and natural wetlands in the floodplain of an African river. Canadian Journal of Fisheries and Aquatic Sciences 70: 543-553. https://doi: 10.1139/cjfas-2012-0403.

Jardine TD, Pettit NE, Warfe DM, Pusey BJ, Ward DP, Douglas MM, Davies PM, Bunn SE (2012) Consumerresource coupling in wet-dry tropical rivers. Journal of Animal Ecology 81: 310-322. https://doi: 10.1111/j.1365-2656.2011.01925. x. 
Jepsen DB, Winemiller KO (2007) Basin geochemistry and isotopic ratios of fishes and basal production sources in four neotropical rivers. Ecology of Freshwater Fish 16: 267-281. https://doi: 10.1111/j.16000633.2006.00218. x.

Junk WJ, Bayley PD, Sparks RE (1989) The flood pulse concept in river-floodplain systems. In: Proceedings of the international large river symposium, pp 110-127

Kondoh M (2003) Foraging Adaptation and the Relationship Between Food-Web Complexity and Stability. Science 299: 1388-1391. https://doi: 10.1126/science.1079154.

Layman CA, Araujo MS, Boucek R, Hammerschlag-Peyer CM, Harrison E, Jud ZR, Matich P, Rosenblatt AE, Vaudo JJ, Yeager L, Post DM, Bearhop S (2012) Applying stable isotopes to examine food-web structure: an overview of analytical tools. Biological Reviews 87: 545-562. https://doi: 10.1111/j.1469185x.2011.00208. $x$.

Legendre L, Rassoulzadegan F (1995) Plankton and nutrient dynamics in marine waters. Ophelia 41: 153172. https://doi: 10.1080/00785236.1995.10422042.

Lewis WS, Hamilton SK, Rodríguez MA, Saunders JF, Lasi MA (2001) Foodweb analysis of the Orinoco floodplain based on production estimates and stable isotope data. Journal of the North American Benthological Society 20: 241-254. https://doi: 10.2307/1468319.

Liem KF (1980) Adaptive Significance of Intra- and Interspecific Differences in the Feeding Repertoires of Cichlid Fishes. American Zoologist 20: 295-314. https://doi: 10.1093/icb/20.1.295.

Lindholm M, Hessen DO, Mosepele K, Wolski P (2007) Food webs and energy fluxes on a seasonal floodplain: The influence of flood size. Wetlands 27: 775-784. https://doi: 10.1672/02775212(2007)27[775: fwaefo]2.0.co;2.

Masese FO, Abrantes KG, Gettel GM, Bouillon S, Irvine K, McClain ME (2015) Are Large Herbivores Vectors of Terrestrial Subsidies for Riverine Food Webs? Ecosystems 18: 686-706. https://doi: 10.1007/s10021015-9859-8.

Masese FO, Kiplagat MJ, González-Quijano CR, Subalusky AL, Dutton CL, Post DM, Singer GA (2020) Hippopotamus are distinct from domestic livestock in their resource subsidies to and effects on aquatic ecosystems. Proceedings of the Royal Society B: Biological Sciences 287: 20193000. https://doi: 10.1098/rspb.2019.3000.

McCann KS (2011) Food webs. Princeton University Press, Princeton, USA.

McCann KS, Hastings A, Huxel G (1998) Weak trophic interactions and the balance of nature. Nature 395: 794-798. https://doi: 10.1038/27427. 
McCann KS, Rasmussen JB, Umbanhowar J (2005) The dynamics of spatially coupled food webs. Ecology Letters 8: 513-523. https://doi: 10.1111/j.1461-0248.2005.00742. x.

McCutchan JH, Lewis WM, Kendall C, McGrath CC (2003) Variation in trophic shift for stable isotope ratios of carbon, nitrogen, and sulfur. Oikos 102: 378-390. https://doi: 10.1034/j.1600-0706.2003.12098. $\mathrm{x}$.

McHugh P, Mclntosh A, Jellyman P (2010) Dual influences of ecosystem size and disturbance on food chain length in streams. Ecology Letters 13: 881-890. https://doi: 10.1111/j.1461-0248.2010.01484. x.

McIntosh AR, Leigh C, Boersma KS, McHugh PA, Febria C, García-Berthou E (2017) Food webs and trophic interactions in intermittent rivers and ephemeral streams. In: Datry T, Bonada N, Boulton A (ed) Intermittent rivers and ephemeral streams, 1st edn.Elsevier Science Publishing Co Inc., San Diego, pp 323347.

McMeans BC, McCann KS, Humphries M, Rooney N, Fisk AT (2015) Food Web Structure in Temporally Forced Ecosystems. Trends in Ecology \& Evolution 30: 662-672. https://doi: 10.1016/j.tree.2015.09.001.

Minagawa M, Wada E (1984) Stepwise enrichment of $15 \mathrm{~N}$ along food chains: Further evidence and the relation between $\delta 15 \mathrm{~N}$ and animal age. Geochimica et Cosmochimica Acta 48: 1135-1140. https://doi: 10.1016/0016-7037(84)90204-7.

Minson DJ (1971) Influence of lignin and silicon on a summative system for assessing the organic matter digestibility of Panicum. Australian Journal of Agricultural Research 22: 589-598. doi: 10.1071/ar9710589.

Moline, M. A., Claustre, H., Frazer, T. K., Schofield, O., \& Vernet, M. 2004. Alteration of the food web along the Antarctic Peninsula in response to a regional warming trend. Global Change Biology 10: 1973-1980. https://doi: 10.1111/j.1365-2486.2004.00825. x.

Ou C, Winemiller KO (2016) Seasonal hydrology shifts production sources supporting fishes in rivers of the Lower Mekong Basin. Canadian Journal of Fisheries and Aquatic Sciences 73: 1342-1362. https://doi: 10.1139/cjfas-2015-0214.

Parnell (2020) simmr: A Stable Isotope Mixing Model. R package version 0.4.1. https://CRAN.Rproject.org/package=simmr

Peel RA, Hill JM, Taylor GC, Weyl OLF (2019) Food Web Structure and Trophic Dynamics of a Fish Community in an Ephemeral Floodplain Lake. Frontiers in Environmental Science 7: https://doi: 10.3389/fenvs.2019.00192.

Phillips DL, Inger R, Bearhop S, Jackson AL, Moore JW, Parnell AC, Semmens BX, Ward EJ (2014) Best practices for use of stable isotope mixing models in food-web studies. Canadian Journal of Zoology 92: 823-835. https://doi: 10.1139/cjz-2014-0127. 
Poff NL, Allan JD, Bain MB, Karr JR, Prestegaard KS, Richter BD, Sparks RE, Stromberg JC (1997) The natural flow regime: A paradigm for river conservation and restoration. BioScience 47: 769-784.

Polis GA, Strong DR (1996) Food Web Complexity and Community Dynamics. The American Naturalist 147: 813-846. https://doi: 10.1086/285880.

Post DM, Layman CA, Arrington DA, Takimoto G, Quattrochi J, Montaña CG (2007) Getting to the fat of the matter: models, methods and assumptions for dealing with lipids in stable isotope analyses. Oecologia 152: 179-189. https://doi: 10.1007/s00442-006-0630-x.

Quezada-Romegialli C, Jackson AL, Hayden B, Kahilainen KK, Lopes C, Harrod C (2018) tRophicPosition, an $r$ package for the Bayesian estimation of trophic position from consumer stable isotope ratios. Methods in Ecology and Evolution 9: 1592-1599. https://doi: 10.1111/2041-210x.13009.

R Core Team (2020) A language and environment for statistical computing. R foundation for statistical computing, Vienna, Austria. URL https://www.R-project.org/

Reid DJ, Quinn GP, Lake PS, Reich P (2008) Terrestrial detritus supports the food webs in lowland intermittent streams of south-eastern Australia: a stable isotope study. Freshwater Biology 53: 20362050. https://doi: 10.1111/j.1365-2427.2008.02025. x.

Renaud SM, Thinh L, Parry DL (1999) The gross chemical composition and fatty acid composition of 18 species of tropical Australian microalgae for possible use in mariculture. Aquaculture 170: 147-159. https://doi: 10.1016/s0044-8486(98)00399-8.

Roach KA (2013) Environmental factors affecting incorporation of terrestrial material into large river food webs. Freshwater Science 32: 283-298. https://doi: 10.1899/12-063.1.

Roach KA, Winemiller KO (2015) Hydrologic regime and turbidity influence entrance of terrestrial material into river food webs. Canadian Journal of Fisheries and Aquatic Sciences 72: 1099-1112. https://doi: 10.1139/cjfas-2014-0459.

Rooney N, McCann KS (2012) Integrating food web diversity, structure and stability. Trends in Ecology \& Evolution 27: 40-46. https://doi: 10.1016/j.tree.2011.09.001.

Rooney N, McCann K, Moore J (2008) A landscape theory for food web architecture. Ecology Letters 11: 867-881. https://doi: 10.1111/j.1461-0248.2008.01193. x.

Skelton PH (2001) A complete guide to the freshwater fishes of Southern Africa. Struik Publishers, Capetown.

Subalusky AL, Dutton CL, Rosi-Marshall EJ, Post DM (2014) The hippopotamus conveyor belt: vectors of carbon and nutrients from terrestrial grasslands to aquatic systems in sub-Saharan Africa. Freshwater Biology 60: 512-525. https://doi: 10.1111/fwb.12474. 
Taylor BW, Flecker AS, Hall RO (2006) Loss of a Harvested Fish Species Disrupts Carbon Flow in a Diverse Tropical River. Science 313: 833-836. https://doi: 10.1126/science.1128223.

Taylor GC, Weyl OLF, Hill JM, Peel RA, Hay CJ (2017) Comparing the fish assemblages and food-web structures of large floodplain rivers. Freshwater Biology 62: 1891-1907. https://doi: 10.1111/fwb.13032.

Thorp JH, Delong MD (1994) The Riverine Productivity Model: An Heuristic View of Carbon Sources and Organic Processing in Large River Ecosystems. Oikos 70: 305. https://doi: 10.2307/3545642.

Thorp JH, Delong MD (2002) Dominance of autochthonous autotrophic carbon in food webs of heterotrophic rivers. Oikos 96: 543-550. https://doi: 10.1034/j.1600-0706.2002.960315. x.

Timoner X, Acuña V, Von Schiller D, Sabater S (2012) Functional responses of stream biofilms to flow cessation, desiccation and rewetting. Freshwater Biology 57: 1565-1578. https://doi: 10.1111/j.13652427.2012.02818. $x$.

Vadeboncoeur Y, Jeppesen E, Vander Zanden MJ, Schierup H, Christoffersen K, Lodge DM (2003) From Greenland to green lakes: Cultural eutrophication and the loss of benthic pathways in lakes. Limnology and Oceanography 48: 1408-1418. https://doi: 10.4319/lo.2003.48.4.1408.

Vander Zanden MJ, Rasmussen JB (1999) Primary consumer $\delta 13 \mathrm{C}$ and $\delta 15 \mathrm{~N}$ and the trophic position of aquatic consumers. Ecology 80: 1395-1404. https://doi: 10.1890/0012-9658(1999)080[1395: pccana]2.0.co;2.

Vander Zanden MJ, Vadeboncoeur Y (2002) Fishes as integrators of benthic and pelagic food webs in lakes. Ecology 83: 2152-2161. https://doi: 10.2307/3072047.

Venarsky MP, Stewart-Koster B, Hunt RJ, Jardine TD, Bunn SE (2020) Spatial and temporal variation of fish community biomass and energy flow throughout a tropical river network. Freshwater Biology 00: 111. https://doi: 10.1111/fwb.13581.

Winemiller K (2004) Floodplain river food webs: generalizations and implications for fisheries management. In: Proceedings of the second international symposium on the management of large rivers for fisheries. Red Plough International Co., Ltd., Bangkok. pp 285-309.

Winemiller KO (1989) Ontogenetic diet shifts and resource partitioning among piscivorous fishes in the Venezuelan ilanos. Environmental Biology of Fishes 26: 177-199. https://doi: 10.1007/bf00004815.

Winemiller KO (1991) Comparative ecology of Serranochromis species (Teleostei: Cichlidae) in the Upper Zambezi River floodplain. Journal of Fish Biology 39: 617-639. https://doi: 10.1111/j.1095-8649. 1991.tb04393. x.

Winemiller KO, Jepsen DB (1998) Effects of seasonality and fish movement on tropical river food webs. Journal of Fish Biology 53: 267-296. https://doi: 10.1111/j.1095-8649. 1998.tb01032. x. 
Winemiller KO, Kelso-Winemiller LC (2003) Food habits of tilapiine cichlids of the Upper Zambezi River and floodplain during the descending phase of the hydrologic cycle. Journal of Fish Biology 63: 120-128. https://doi: 10.1046/j.1095-8649.2003.00134. x.

Winemiller KO, Kelso-Winemiller LC (1996) Comparative ecology of catfishes of the Upper Zambezi River floodplain. Journal of Fish Biology 49: 1043-1061. https://doi: 10.1111/j.1095-8649. 1996.tb01777. x.

Winemiller KO, Kelso-Winemiller LC (1994) Comparative ecology of the African pike, Hepsetus odoe, and tigerfish, Hydrocynus forskahlii, in the Zambezi River floodplain. Journal of Fish Biology 45: 211-225. https://doi: 10.1111/j.1095-8649. 1994.tb01301. x.

Wolkovich EM, Allesina S, Cottingham KL, Moore JC, Sandin SA, de Mazancourt C (2014) Linking the green and brown worlds: the prevalence and effect of multichannel feeding in food webs. Ecology 95: 3376-3386. https://doi: 10.1890/13-1721.1.

Zeug SC, Winemiller KO (2008) Evidence supporting the importance of terrestrial carbon in a large-river food web. Ecology 89: 1733-1743. https://doi: 10.1890/07-1064.1.

Zou K, Thébault E, Lacroix G, Barot S (2016) Interactions between the green and brown food web determine ecosystem functioning. Functional Ecology 30: 1454-1465. https://doi: 10.1111/13652435.12626.

\section{Declarations}

Acknowledgments We would like to thank Choto J. Choto and Aaron Samoxa of the Department of Wildlife and National Parks (DWNP) in Maun for logistical support and assistance in the field during the first sampling in August 2017. Ketlhatlogile Mosepele and Ineelo Mosie of the Okavango Research Institute assisted with gill nets and an aluminum speed boat. The Anti-poaching unit of the DWNP provided a motor engine that could drive on relatively shallow water.

\section{Declarations}

Funding This study was financially supported by the Botswana International University of Science and Technology, through a graduate fellowship awarded to Thethela Bokhutlo.

Conflicts of interest/competing interests The authors declare no conflicts of interest.

Ethics approval This study complied with the requirements of the Texas A\&M Animal Ethics Committee (TAMU AUP IACUC 2017-0069). Data collection was permitted through a director's permit no. 00000654A, which was obtained from the DWNP. 
Data and code availability All data and code have not been archived and are available from the corresponding author upon request.

\section{Tables}

Table 1 Sample size $(n)$, mean carbon and nitrogen isotope ratios $\left(\delta^{13} C, \delta^{15} N\right)$ and their standard deviations (SD) for basal production sources from the intermittent reaches of the lower Okavango Delta

\begin{tabular}{|lllllll|}
\hline Source & Species & $n$ & Mean $\delta^{13} \mathrm{C}$ & $S D \delta^{13} \mathrm{C}$ & Mean $\delta^{15} \mathrm{~N}$ & $S D \delta^{15} \mathrm{~N}$ \\
\hline Aquatic macrophyte & Aquatic plant & 19 & -26.90 & 1.63 & 3.39 & 2.92 \\
& Hippo grass & 5 & -27.30 & 1.24 & 2.78 & 1.21 \\
\hline C3 plant & Riparian tree & 80 & -28.19 & 1.65 & 3.27 & 2.32 \\
\hline C4 grass & Shrub & 8 & -29.30 & 0.49 & 4.60 & 1.36 \\
Periphyton & & 17 & -12.47 & 0.72 & 3.55 & 3.09 \\
Seston & & 18 & -29.17 & 2.90 & 2.76 & 2.56 \\
Water lily & & 40 & -25.79 & 1.24 & 4.67 & 1.58 \\
\hline
\end{tabular}

Table 2 Sample size $(n)$, mean carbon and nitrogen isotope ratios $\left(\delta^{13} \mathrm{C}, \delta^{15} \mathrm{~N}\right)$ and their standard deviations (SD) for fish species that were analyzed in this study 


\begin{tabular}{|c|c|c|c|c|c|}
\hline Species & $n$ & Mean $\delta^{13} C$ & $S D \delta^{13} C$ & Mean $\delta^{15} \mathrm{~N}$ & $S D \delta^{15} \mathrm{~N}$ \\
\hline Oreochromis andersonii & 7 & -27.04 & 1.85 & 6.47 & 0.72 \\
\hline Oreochromis macrochir & 1 & -27.58 & - & 6.13 & - \\
\hline Coptodon rendalli & 11 & -22.39 & 2.36 & 7.70 & 0.76 \\
\hline Tilapia sparmanii & 34 & -25.15 & 2.16 & 7.25 & 0.74 \\
\hline Enteromius bifrenatus & 2 & -22.69 & 1.99 & 7.45 & 0.01 \\
\hline Brycinus lateralis & 54 & -22.44 & 1.81 & 8.99 & 0.84 \\
\hline Enteromius paludinosus & 16 & -19.85 & 2.97 & 8.09 & 0.39 \\
\hline Enteromius poechi & 2 & -17.43 & 1.68 & 8.80 & 1.97 \\
\hline Mormyrus lacerda & 11 & -23.28 & 2.45 & 7.26 & 0.70 \\
\hline Marcusenius altisambesi & 70 & -24.57 & 2.09 & 7.30 & 1.05 \\
\hline Pharyngochromis acuticeps & 9 & -21.98 & 1.88 & 8.89 & 0.71 \\
\hline Petrocephalus okovangoensis & 34 & -25.61 & 1.36 & 7.66 & 0.81 \\
\hline Pseudocrenilabrus philander & 4 & -23.77 & 3.37 & 7.99 & 0.81 \\
\hline Sargochromis carlottae & 3 & -22.55 & 0.98 & 10.22 & 0.46 \\
\hline Sargochromis condringtonii & 9 & -22.45 & 2.00 & 8.88 & 0.77 \\
\hline Synodontis spp & 37 & -25.41 & 2.50 & 8.72 & 1.03 \\
\hline Clarias gariepinus & 25 & -23.25 & 2.08 & 9.81 & 0.73 \\
\hline Clarias ngamensis & 3 & -24.47 & 0.68 & 9.49 & 0.65 \\
\hline Hepsetus cuvieri & 47 & -22.61 & 2.12 & 9.32 & 0.82 \\
\hline Hydrocynus vittatus & 1 & -25.59 & - & 9.97 & - \\
\hline Serranochromis altus & 7 & -24.09 & 1.68 & 9.89 & 0.88 \\
\hline Serranochromis angusticeps & 11 & -23.69 & 1.93 & 9.85 & 0.89 \\
\hline Schilbe intermedius & 75 & -24.23 & 2.22 & 8.29 & 1.16 \\
\hline Serranochromis macrocephalus & 7 & -22.27 & 1.36 & 10.51 & 0.76 \\
\hline Serranochromis thumbergi & 6 & -25.09 & 3.18 & 9.49 & 0.86 \\
\hline
\end{tabular}

\section{Figures}




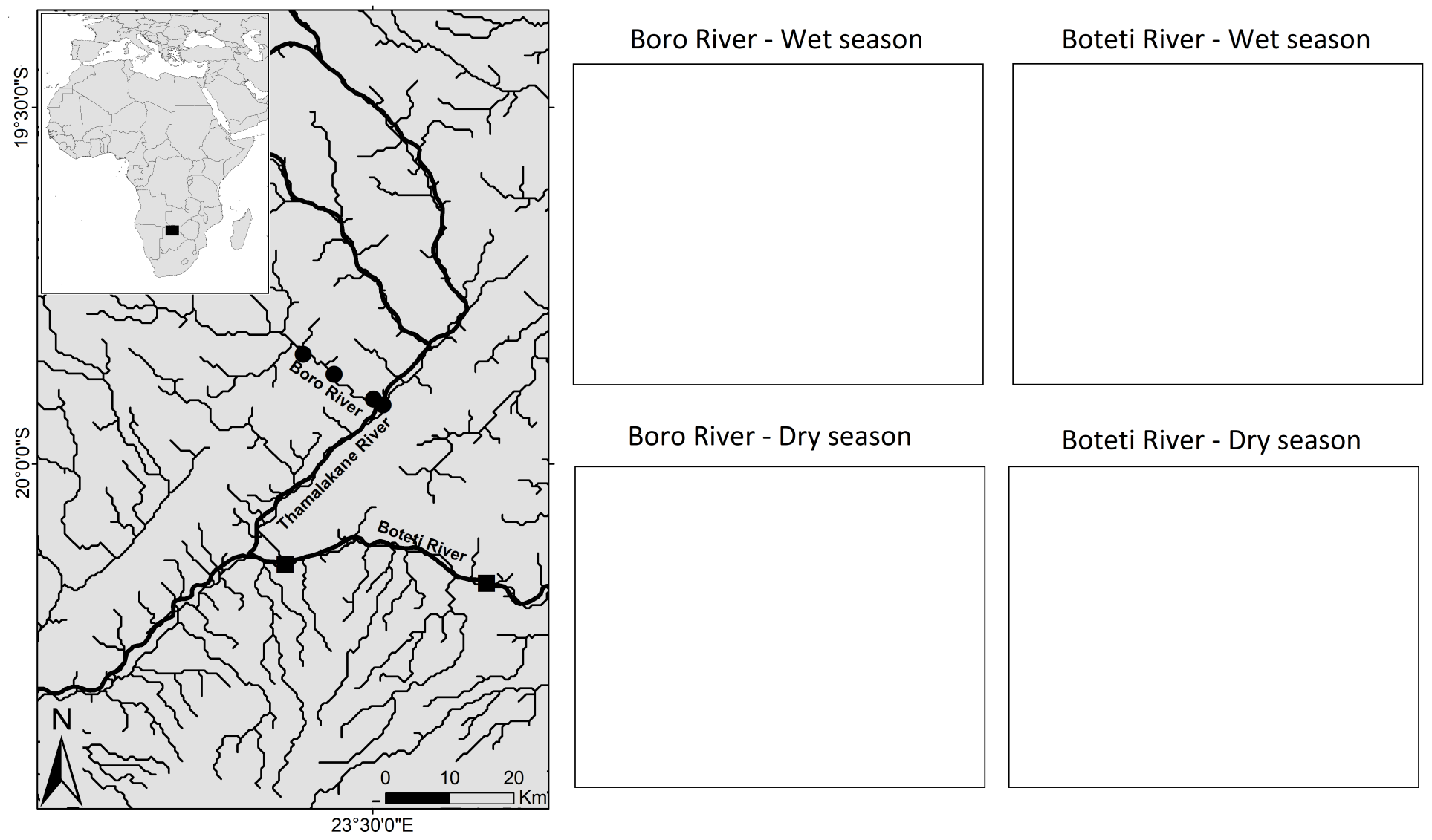

Figure 1

Sampling sites in Boro and Boteti Rivers during the wet and dry seasons. During the wet season, water volume was high and a motorised boat was used to access sampling sites 

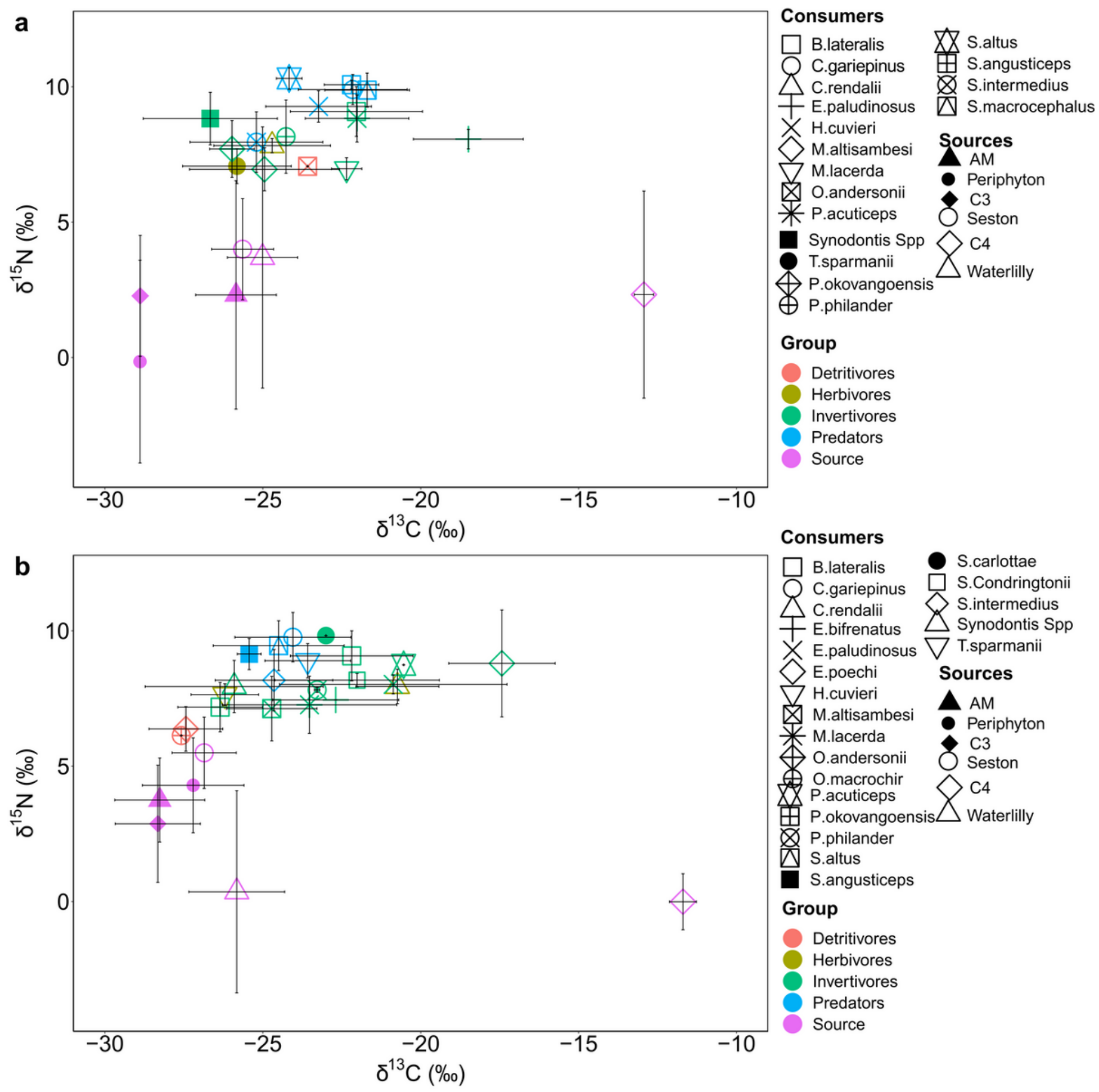

\section{Consumers}

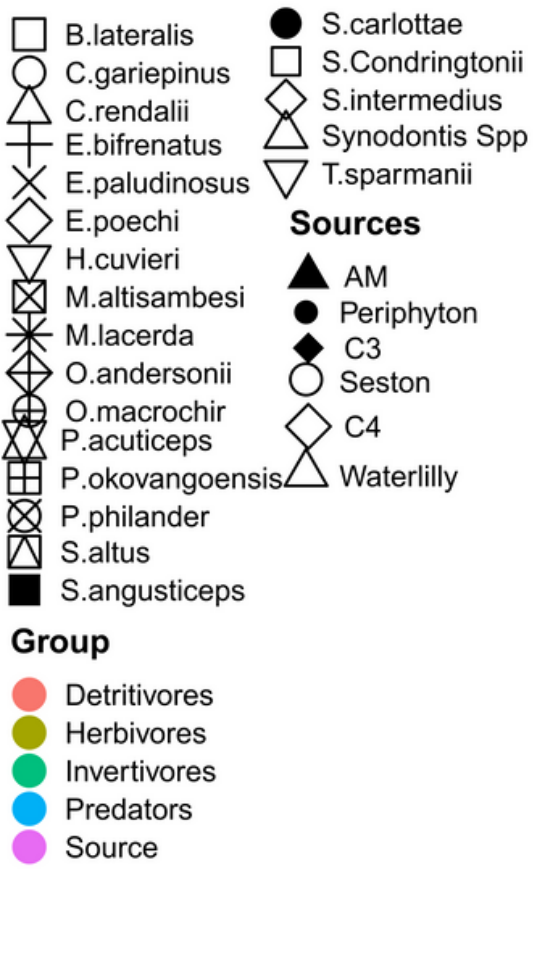

\section{Figure 2}

Biplots of mean $\delta 13 \mathrm{C}$ and $\delta 15 \mathrm{~N}$ ( \pm standard deviation) for basal production sources and fishes from Boro River during wet (a) and dry (b) seasons 

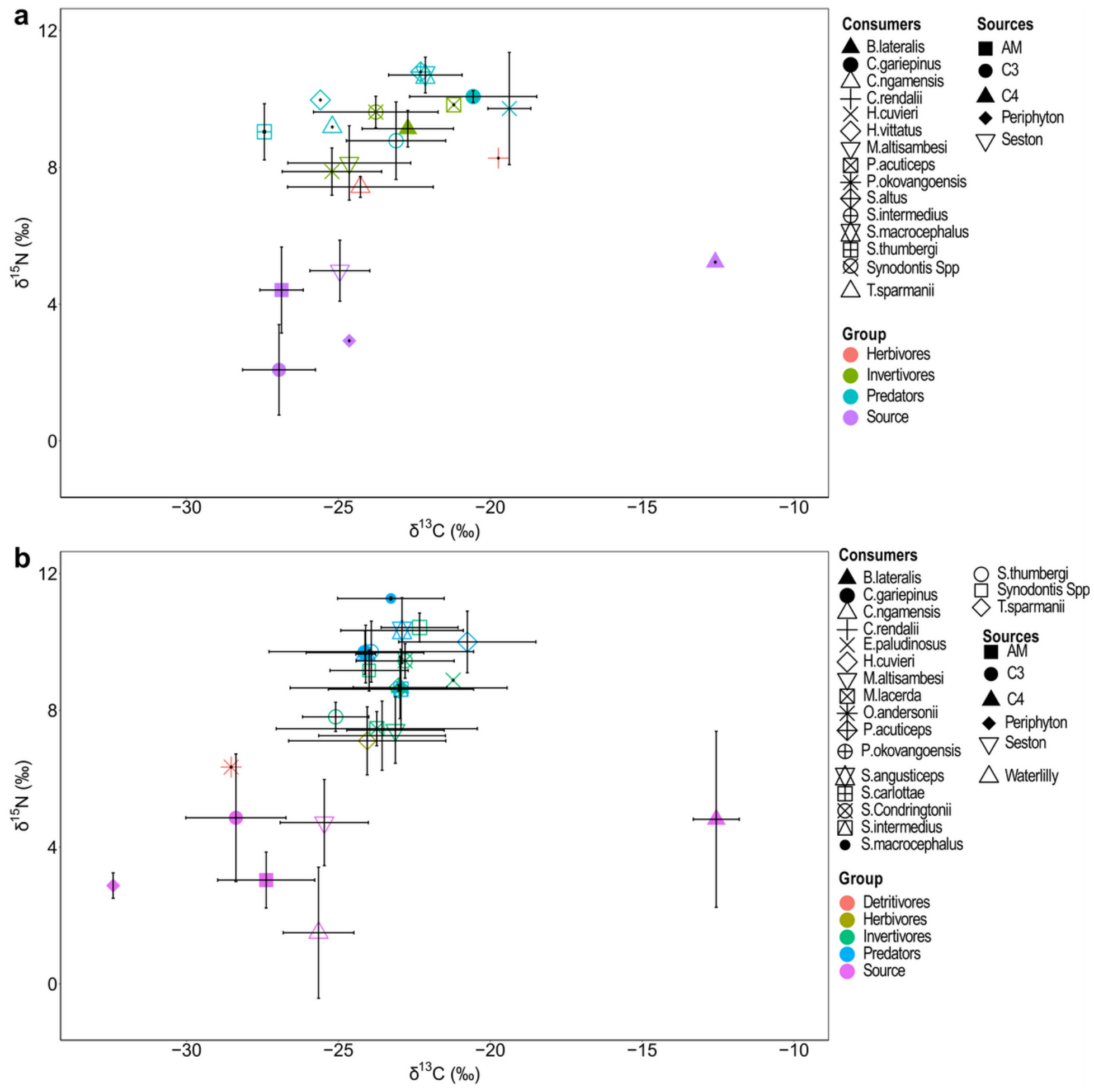

Figure 3

Biplots of mean $\delta 13 \mathrm{C}$ and $\delta 15 \mathrm{~N}$ ( \pm standard deviation) for basal production sources and fishes from Boteti River during wet (a) and dry (b) seasons 


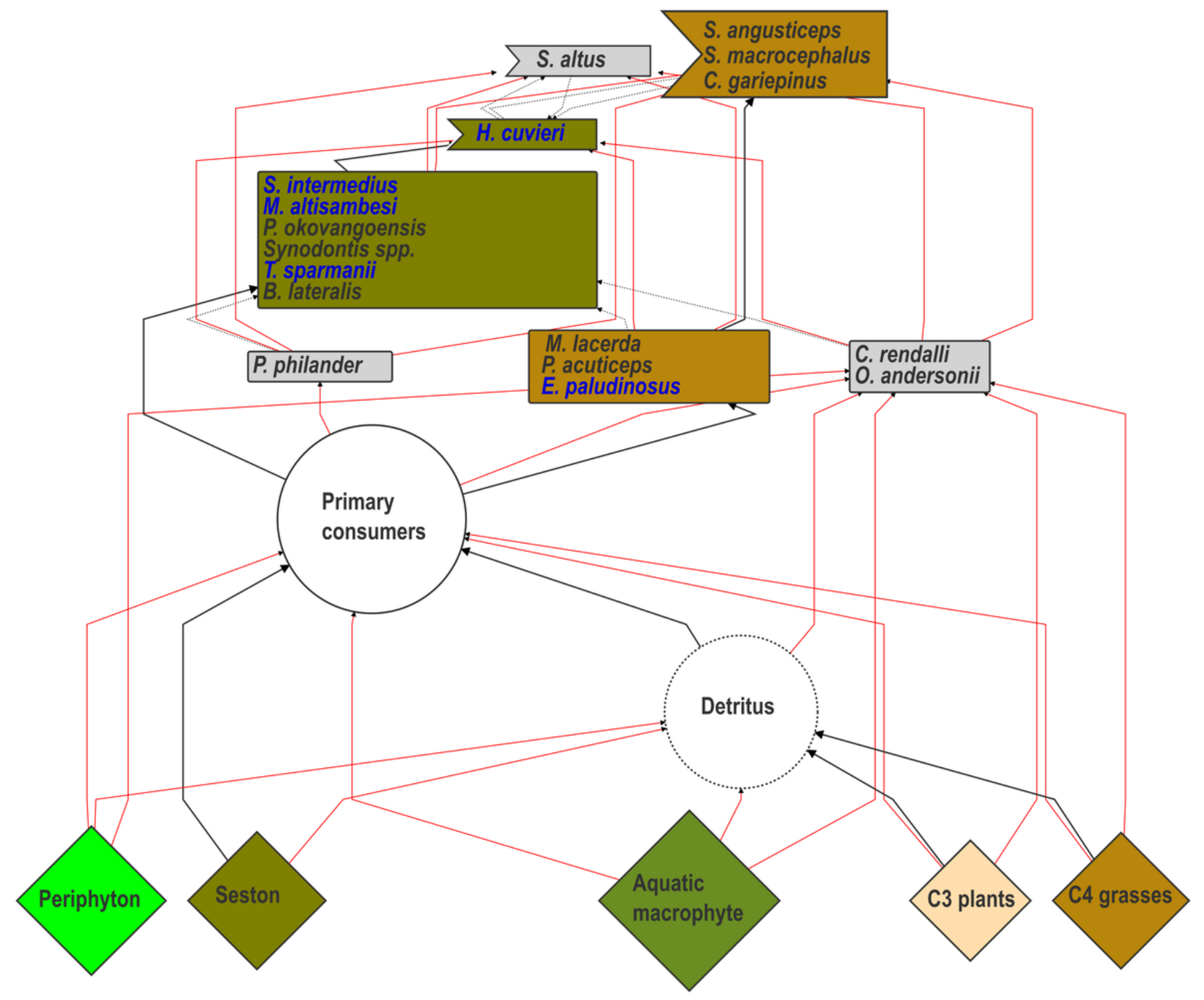

Figure 4

Energy flow and fish trophic interactions in the Boro River during the wet season. Modal trophic position ranged from 3.15 - 4.32 (Table S2). Different node shapes and connecting arrows represent energy pathways and the species they support (food web compartments) categorized vertically by modal trophic position: Basal sources ( ), detritus (dotted circle), primary consumers ( ), species with modal trophic position < 3.94 ( ), and species with modal trophic position $\geq 3.94$ ( ). Solid black arrows represent major energy pathways (contributing $\geq 20 \%$ to fish biomass), and red arrows represent pathways contributing $<20 \%$ of basal sources to fish biomass. Dotted arrows show feeding interactions within the same trophic group. If a population derived $\geq 20 \%$ of its tissues from more than one source, it was assigned to the compartment with the greatest contribution. Within a compartment, populations that assimilated $>30 \%$ of the resource are shown in blue. Consumer-resource interactions were inferred from literature reporting diets of these species in the Upper Zambezi river-floodplain system (Winemiller 1991, Winemiller and 
Kelso-Winemiller 1994, 1996, 2003). Autochthonous sources are shown in green and allochthonous sources in brown

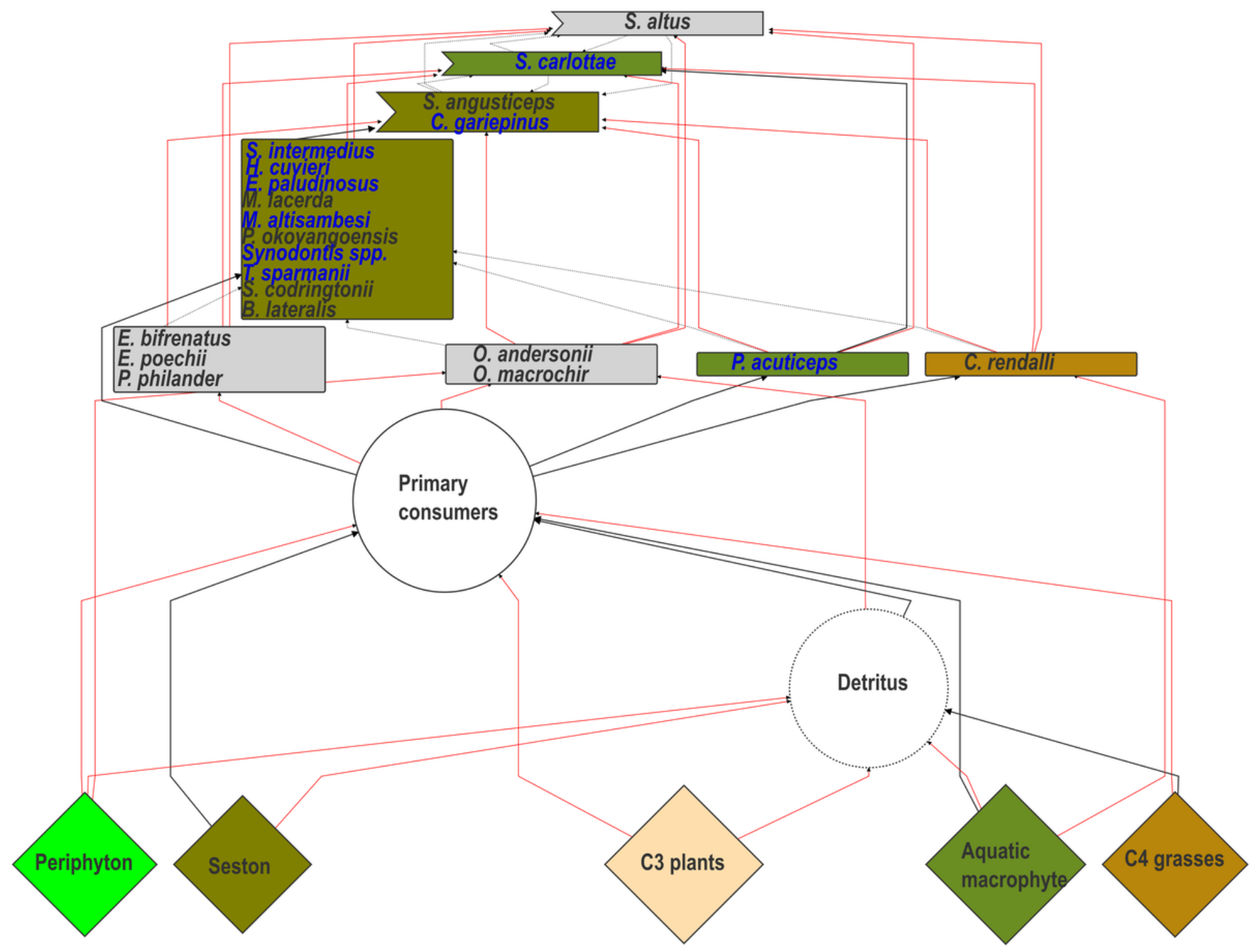

\section{Figure 5}

Energy flow and fish trophic interactions in Boro River during the dry season. Modal trophic position ranged from 2.42 - 3.61 (Table S3). Different node shapes and connecting arrows represent energy pathways and the species they support (food web compartments) categorized vertically by modal trophic position: Basal sources ( ), detritus (dotted circle), primary consumers ( ), species with modal trophic position < 3.49 ( ), and species with modal trophic position $\geq 3.49$ ( ). Solid black arrows represent major energy pathways (contributing $\geq 20 \%$ to fish biomass), and red arrows represent pathways contributing $<20 \%$ of basal sources to fish biomass. Dotted arrows show feeding interactions within the same trophic group. If a population derived $\geq 20 \%$ of its tissues from more than one source, it was assigned to the compartment with the greatest contribution. Within a compartment, populations that assimilated $>30 \%$ of the resource are shown in blue. Consumer-resource interactions were inferred from literature reporting diets of these species in the Upper Zambezi river-floodplain system (Winemiller 1991, Winemiller and 
Kelso-Winemiller 1994, 1996, 2003). Autochthonous sources are shown in green and allochthonous sources in brown

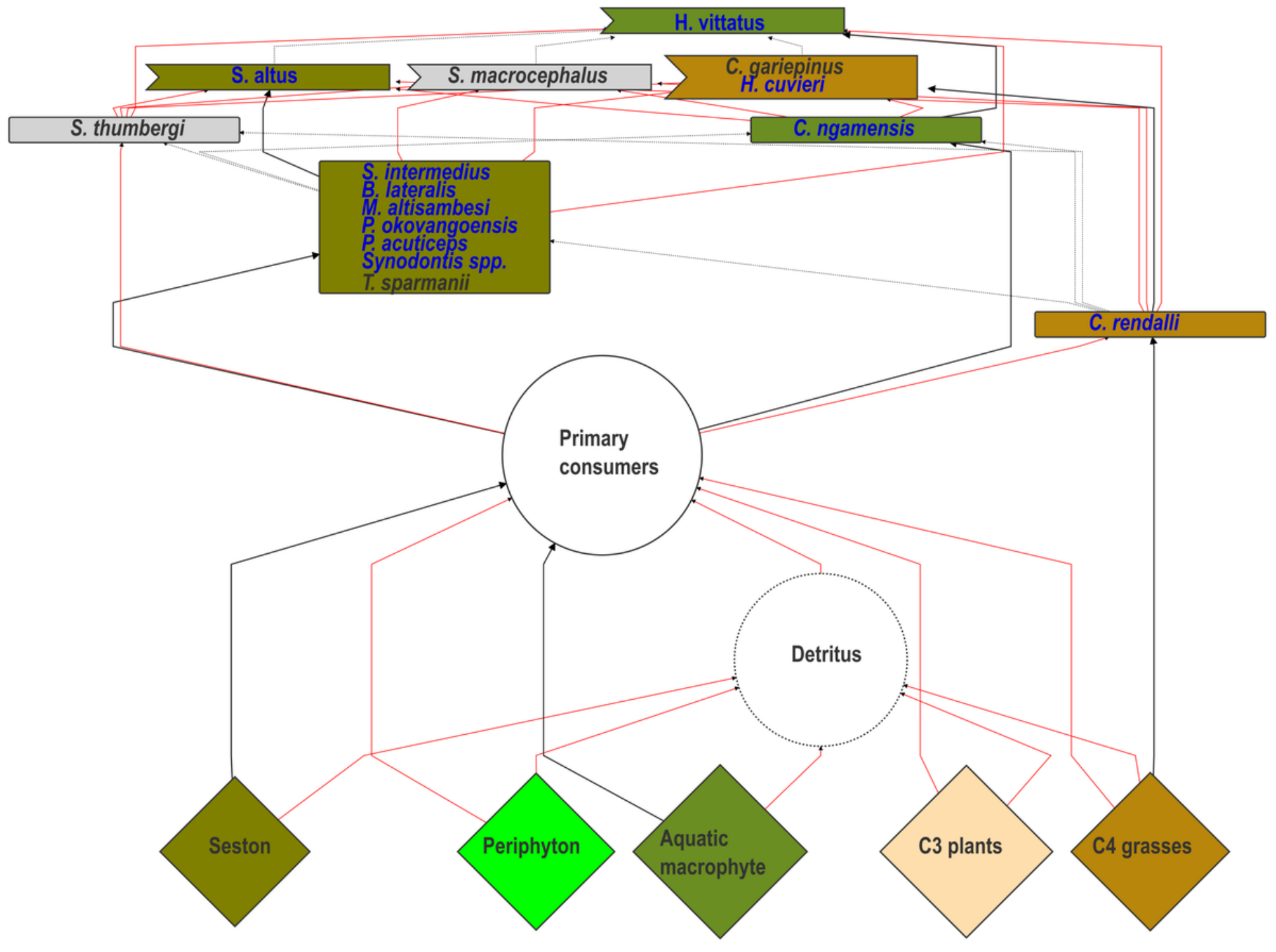

\section{Figure 6}

Energy flow and fish trophic interactions in Boteti River during the wet season. Modal trophic position ranged from $2.84-4.06$ (Table S4). Different node shapes and connecting arrows represent energy pathways and the species they support (food web compartments) categorized vertically by modal trophic position: Basal sources ( ), detritus (dotted circle), primary consumers ( ), fish with modal trophic position $<3.71$ ( ), and fish with modal trophic position $\geq 3.71$ ( ). Solid black arrows represent major energy pathways (contributing $\geq 20 \%$ to fish biomass), and red arrows represent pathways contributing $<20 \%$ of basal sources to fish biomass. Dotted arrows show feeding interactions within the same trophic group. If a population derived $\geq 20 \%$ of its tissues from more than one source, it was assigned to the compartment with the greatest contribution. Within a compartment, populations that assimilated $>30 \%$ of the resource are shown in blue. Consumer-resource interactions were inferred from literature reporting diets of these species in the Upper Zambezi river-floodplain system (Winemiller 1991, Winemiller and Kelso-Winemiller $1994,1996,2003)$. Autochthonous sources are shown in green and allochthonous sources in brown 


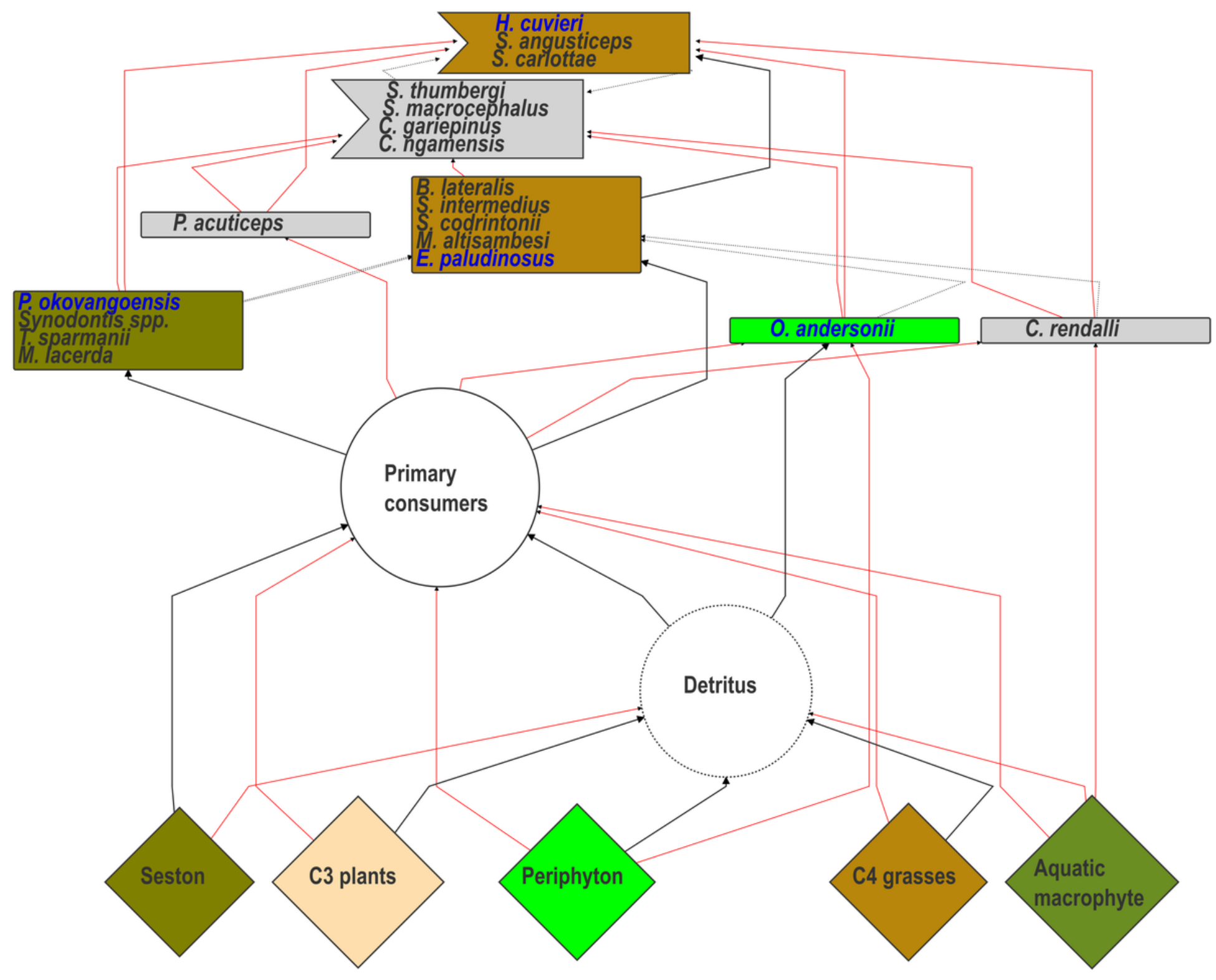

Figure 7

Energy flow and fish trophic interactions in Boteti River during the dry season. Modal trophic position ranged from $2.62-4.34$ (Table S5). Different node shapes and connecting arrows represent energy pathways and the species they support (food web compartments) categorized vertically by modal trophic position: Basal sources ( ), detritus (dotted circle) primary consumers ( ), fish with modal trophic position $<3.78$ ( ), and fish with modal trophic position $\geq 3.78$ ( ). Solid black arrows represent major energy pathways (contributing $\geq 20 \%$ to fish biomass), and red arrows represent pathways contributing $<20 \%$ of basal sources to fish biomass. Dotted arrows show feeding interactions within the same trophic group. If a population derived $\geq 20 \%$ of its tissues from more than one source, it was assigned to the compartment with the greatest contribution. Within a compartment, populations that assimilated $>30 \%$ of the resource are shown in blue. Consumer-resource interactions were inferred from literature reporting diets of these species in the Upper Zambezi river-floodplain system (Winemiller 1991, Winemiller and Kelso-Winemiller $1994,1996,2003)$. Autochthonous sources are shown in green and allochthonous sources in brown 


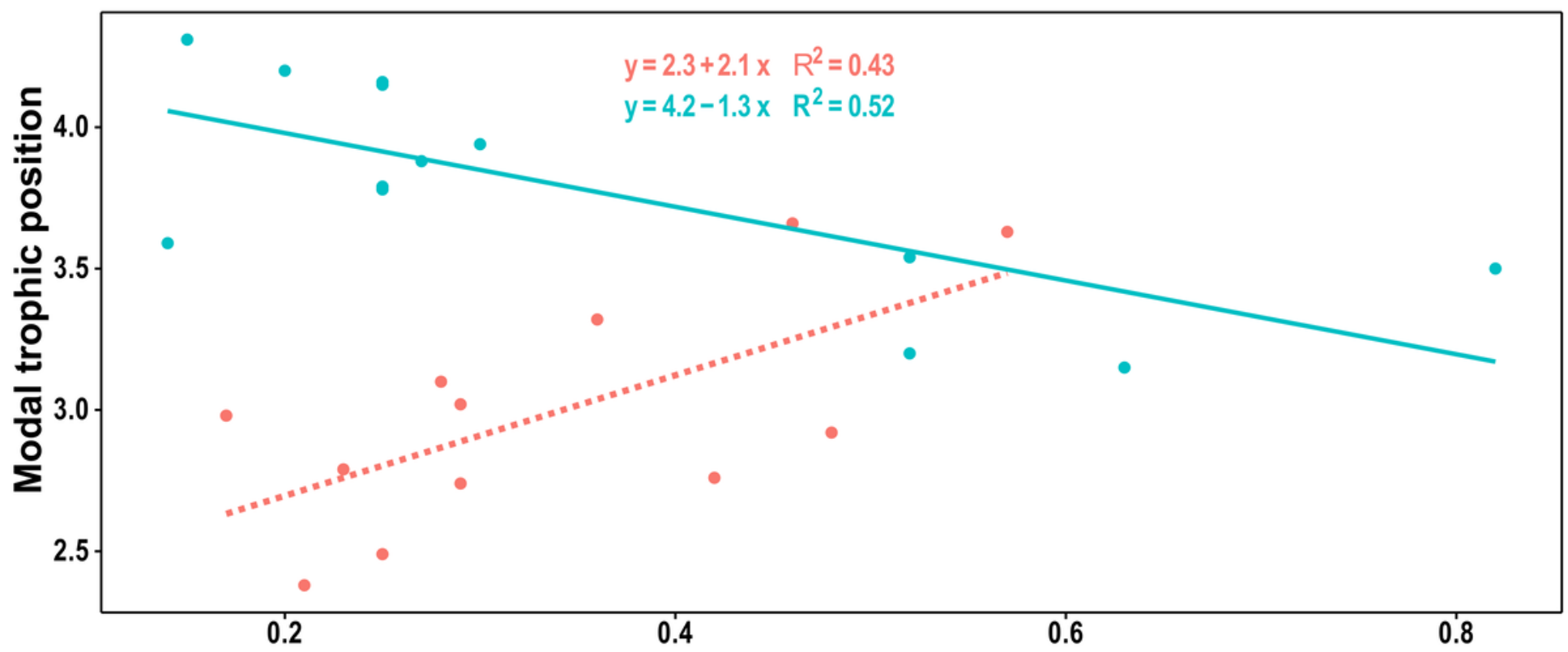

b

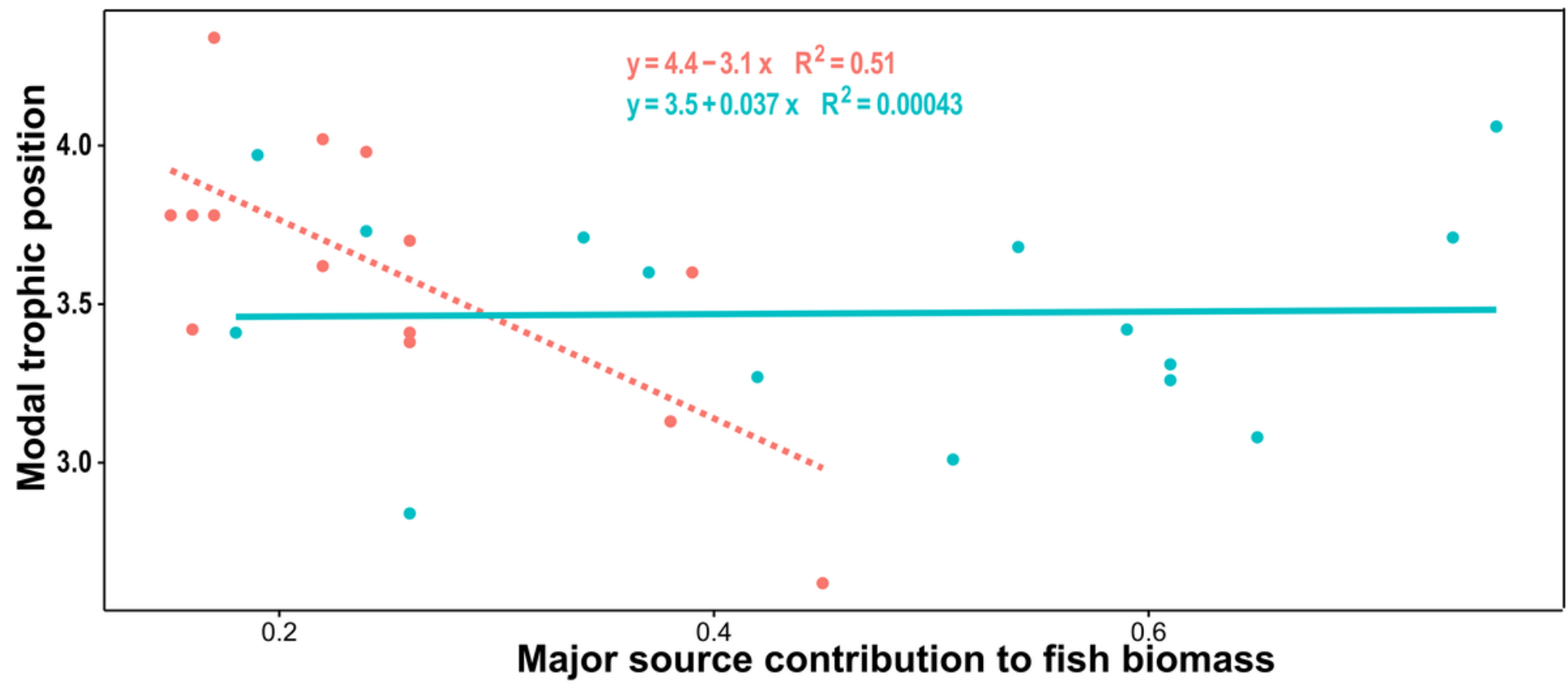

Figure 8

The relationship between trophic position and the degree of dependence on major basal sources in the Boro (a) and Boteti (b) Rivers during wet and dry seasons. In the Boro River, trophic position significantly decreased with increased dependence on a single major basal resource during the wet season. During the dry season, trophic position significantly increased with increased dependence on a single major basal resource. In the Boteti River, trophic position significantly decreased with increasing dependence on a 
single major basal resource during the dry season. During the wet season, the relationship between trophic position and the degree of dependence on a single major resource was not significant

\section{Supplementary Files}

This is a list of supplementary files associated with this preprint. Click to download.

- SupplementaryInformation.docx 